\title{
The Prisoners of Perote
}


Barker Texas History Center Series, No. 1 


\section{The Prisoners of Perote}

Containing a Journal Kept by the Author, Who Was Captured by the Mexicans, at Mier,

December 25, I 842, and Released from Perote, May I 6, I 844

by William Preston Stapp

Illustrations by Charles Shaw

University of Texas Press Austin 
Library of Congress Cataloging in Publication Data

Stapp, William Preston.

The prisoners of Perote.

(Barker Texas History Center series, no. I)

Reprint of the 1845 ed. published by G. B. Zieber, Philadelphia; with new foreword.

I. Mier Expedition, 1842-Personal narratives.

2. Stapp, William Preston. 3. Texas-Militia-Biography.

4. Soldiers-Texas-Biography. 5. Mexico-Description and travel. I. Title. II. Series: Eugene C.

Barker Texas History Center. Barker Texas History Center

Series, no. $\mathrm{r}$.

F390.S79 I 977 976.4'04'0924 77-22425

ISBN 0-292-76442-I

Foreword and illustrations copyright (c) 1977

by the University of Texas Press

All rights reserved

Printed in the United States of America

This edition is reset from the publication by

G. B. Zieber and Company, Philadelphia, I 845

ISBN 978-0-292-78424-6 (library e-book)

ISBN 978-0-292-78426-0 (individual e-book) 


\section{TO GENERAL MILTON STAPP,}

Madison, Indiana.

Sir,-

Your kindness in administering to my necessities, while a prisoner in Mexico, and the assiduity with which you prosecuted your application for my release from that imprisonment, and your final success in procuring my liberty, deserves, as it has received, the highest reward that a grateful heart can give. And your friendship to me shall be held in grateful recollection to the latest hour of my life. More than this, I have not in my power to bestow, except it be to give you a faithful history of that eventful period of my life; which you will find in the following pages, and which is here most respectfully inscribed to you, by one who is proud to acknowledge you as his friend, and most earnestly desires that your life may be long, happy, and useful.

I am Sir,

Yours, with great respect, WILLIAM P. STAPP. 
THIS PAGE INTENTIONALLY LEFT BLANK 